The Hayworth: A Lowland Vaccary Site in South-East England

By Andrew Margetts ${ }^{1}$

REMAINS OF AN 11th-13th century farmstead were revealed during excavations within part of 'The Hayworth', an early enclosure on the 'lost' manor of Trubwick, (West Sussex). ${ }^{2}$ Historical, landscape and toponymic evidence has been utilised to set the archaeological activity in context. It seems probable that the excavated site and the Hayworth enclosure more broadly relate to a specialised cattle rearing or vaccary farm. The site represents the most completely excavated vaccary complex yet known, and is the first recognisable example from the Wealden region in south-east England

The discovery has important implications for our current understanding of medieval Wealden economy and environment, as well as patterns of settlement evolution. Evidence suggests this site can be linked with the traditions of Anglo-Saxon out pasture and transhumance. This article explores the evidence from this site for the transition from a seasonal pasture to a permanent 12th-century manorial establishment held in severalty. The likely form of a vaccary complex is established and the potential for the existence of these specialised cattle 'ranches' and dairies is explored.

\title{
INTRODUCTION
}

They in their times have not known any other claim, to take of right any profits, within the waste aforesaid, but only the lord of Trubwicke their tenants, except waifs, strayes and that the tenants only, have common of pasture there and none other, and this they have heard their ancestors and forefathers say also, and this as they think it, has been used out of time of mind". ${ }^{3}$

The work presented here largely concerns a ring-fenced farm of probable early type known as 'the Hayworth' (located in the historic parish of Cuckfield, West Sussex). Along with the holdings of Bolnore and Wigperry this comprised part of the manor of Trubwick, a onetime subsidiary holding and 'outlier' of the manor of Plumpton Boscage. ${ }^{4}$ Bolnore lies to the south-west of the modern town of Haywards Heath (a post-medieval development founded after the arrival of the railway in 1841) and to the south-east of the parochial centre of Cuckfield (Fig 1). It is located close to the boundary between the High and Low Weald, an area comprising a well-wooded anciently enclosed landscape with small scale settlements and isolated farms. The medieval manor of Trubwick was created by subinfeudation from Plumpton sometime between the 10th and the mid-13th centuries. This fits with Alan Everitt's fourth stage of medieval Wealden development - a time when post-Conquest farms bore the names of their early owners. ${ }^{5}$ The name Boscage, which derives from the Norman French boscage/bocage 'masses of trees or shrubs or wooded scenery', indicates it was primarily concerned with the management of Plumpton's Wealden holdings.

The site was assessed and excavated between 2004 and $2011 .{ }^{6}$ Despite the lack of bone survival, the archaeological remains clearly relate to a farm that dealt with livestock. It is the most completely excavated vaccary yet known, and certainly the most intensively investigated example from lowland Britain. As such, the archaeological remains have the potential to not only illuminate the workings of a specific vaccary complex, but also present an opportunity to explore this class of livestock establishment in general. The additional significance of the site is signalled by its association with place-names indicative of Anglo- 
Saxon pastoral origins which contain Old English elements such as wic 'a dwelling, a building or collection of buildings for special purposes, a farm, a dairy farm ${ }^{7}$, word 'an enclosure' ${ }^{8}$, and possibly haga 'a hedge, an enclosure' ${ }^{\text {' }}$. These may point to the longevity of medieval livestock husbandry, both at this site and within the Wealden region. The recovery of important paleoenvironmental remains also aids understanding of the pastoral exploitation and medieval modification of the regions woodlands.

\section{PREVIOUS INVESTIGATIONS}

PASTORALISM

Past research into the agrarian economies of early and later medieval Britain has been heavily orientated towards areas of the country characterized by the 'Midlands system' of open field farming and nucleated villages. This area, and the method of farming it epitomised, termed by Brian Roberts and Stuart Wrathmell ${ }^{10}$ as the 'Central Province', could now be said to be reasonably well understood. As a consequence it has been an increasing trend over the last decade or so to redress this 'Midlands-centric'11 view of medieval landscape archaeology by exploring regions beyond this zone. This has occurred alongside increased consideration of areas which show a pastoral emphasis rather than an able focus. Early pioneering work such as that by Kathleen Biddick, ${ }^{12}$ has sought to place livestock farming on an equal footing with cereal production, and has more recently been augmented by (among others) Harold Fox's seminal posthumous publication of Dartmoor's Alluring Uplands. ${ }^{13}$ This influential work based on evidence from south-west England revealed the importance of seasonal pastoralism and transhumance which tied an upland landscape to the surrounding lowlands. It was also successful in tracing the movement from early medieval 'personal' to later medieval 'impersonal' transhumance, as well as highlighting the importance of place-name elements, that indicate locations of summer dairying (eg Old English butere 'butter' ${ }^{14}$ and smeoru 'fat, grease, lard' $\left.{ }^{15}\right)$. This regional study, with its national applications, has more recently been complimented by a wide ranging and upto date synthesis of Anglo-Saxon Farms and Farming by Debby Banham and Rosamond Faith. ${ }^{16}$

VACCARIES

Before entering into detailed discussion of the excavation results it is pertinent to pause and briefly outline the nature of vaccary establishments and their history. Vaccaries are largely viewed as a 12th- and 13th-century feature of 'marginal' upland regions and it has been northern England, in particular Cumbria, Yorkshire and Lancashire ${ }^{17}$ where they have received the majority of scholarly attention. Nevertheless, Fox's discussion of the pastoral systems of Dartmoor also brought one possible example to light ${ }^{18}$ and Biddick's ${ }^{19}$ work on the estate of Peterborough Abbey (historically Northamptonshire now Cambridgeshire) showed the presence of specialised breeding herds and a vaccary at Oxney. ${ }^{20}$

Vaccary establishments comprised areas of leased pastures producing beef stock, milk, butter and cheese and the draught oxen necessary for regions of greater arable potential. They were part of the lord's forest demesne, whether or not they were farmed directly for his benefit. ${ }^{21}$ The cattle were run on areas that comprised two major landscape elements, an enclosed plot of wood and/or meadow and an expanse of 'open' grazing. The enclosures, which seem to be the defining landscape features of a vaccary, ${ }^{22}$ had at least one stock funnel or driftway allowing the herd to move between the site and nearby pastures. ${ }^{23}$ Several farm buildings were clustered together within the enclosure's interior ${ }^{24}$ 
and these included a dwelling for the cow keeper (Latin vaccarii) and his family, the cowhouse (Latin vaccaria) and possibly (as in the case of the Gatesgarth vaccary, Buttermere) a house for hay and calves. ${ }^{25}$

Further details of these enclosure systems have been illustrated through important landscape work in Lancashire. This has shown that vaccary establishments can be characterised by a landscape form of 'double-oval'. ${ }^{26}$ These comprise two large, often adjacent enclosures each up to half a mile across (Fig 2). Their bounds are frequently defined by footpaths or lanes as well as large banks, ditches or streams. The 'double-oval' comprised a larger pastoral unit with stock funnels leading onto upland with a smaller oval that contained field divisions intended for arable, pasture and convertible land. ${ }^{27}$ It is clear that the ovals acted as self-contained units ${ }^{28}$ and they seem to have been deliberately sited so that a watercourse runs through their centre.

The requirement of vaccaries to be sited near expanses of open grazing led to a distribution close to royal forest or baronial chase. They are often located in side valleys ${ }^{29}$ and have been classed as a land-use element that occurred within areas of dispersed settlement, ${ }^{30}$ especially areas with a cultural history of seasonal exploitation. Indeed, historic records associated with some vaccaries show a gradual transition from a pasture in the forest to a fully functioning vaccaria. ${ }^{31}$

\section{THE HAYWORTH'S LANDSCAPE CONTEXT: THE SUSSEX WEALD}

It was Hilaire Belloc ${ }^{32}$ who wrote: 'unless a man understands the Weald, he cannot easily write about the beginnings of England', and it is true that the region is important for the study of medieval settlement and landscape. Nevertheless, the area has always suffered from a dearth of archaeological work in comparison to the nearby 'higher profile' districts of London, the South Downs and the Coastal Plain. This is partly due to a perception of the area as an unrewarding expanse of marginal wood and clay-land, resistant to early settlement and agriculture. The poverty and heaviness of the soils and the prevalence of dense woodland in the past has led to an outdated view that the region was, for most of its history, an untamed wilderness. It is now thought highly unlikely that the Weald survived long as primordial wildwood. Indeed, paleoenvironmental analysis now indicates that forest clearance by humans was occurring, at least in a localised form, as early as the Mesolithic. ${ }^{33}$

The Weald is characterised by high densities of settlement dispersion ${ }^{34}$ and Everitt has viewed this prevailing settlement pattern (in a Kentish context) as clearly contrasting with the nucleated agricultural settlements of areas such as the Midlands. ${ }^{35}$ The origins of this dispersion may be linked to the prevalence of woodland and a history of pastoralism rather than cooperative arable farming. The pastoral heritage may have led to isolated stock farms rather than agricultural communities clustered together in villages. ${ }^{36}$ It may often be the case in the Sussex Weald that the villages and towns are therefore of later origin than the surrounding farms. Villages and churches may have evolved to supply markets and parochial centres to the isolated farmsteads that surround them.

The Anglo-Saxon Weald was possibly witness to a re-invigoration of settlement following decline in use during the late Roman period. The environment may have largely comprised something akin to wood-pasture with more extensive areas of forest. ${ }^{37}$ It should not be assumed that such generalisations in land-use would indicate that the Weald was occupied by uniform landscape types. A more complex picture is more likely, comprising an amalgam of differing methods of exploitation individually suited to the character of the area. ${ }^{38}$ Everitt has suggested a phased process of development in the medieval Weald of 
Kent ${ }^{39}$ and parallels may be suggested with the Sussex Weald ${ }^{40}$ Of course it may be too simplistic to view the evolution of Wealden exploitation as phased and gradual, however, until more excavation evidence is forthcoming it will remain a useful model. Currently, perhaps the most valuable indicator of Anglo-Saxon period exploitation of the area is derived from toponymic evidence. The Old English place-names of the region reflect a pastoral model of settlement and land-use with names such as falod 'a fold', ${ }^{41}$ denn 'a woodland pasture, especially for swine', ${ }^{42}$ (ge)sell'a shed, a shelter for animals, a herdsman's hut', ${ }^{43}$ and wic 'a dwelling, a building or collection of buildings for special purposes, a farm, a dairy farm', ${ }^{44}$ together being indicative of an area where livestock regimes and woodland exploitation dominated.

It is likely that during the 6th century the Sussex Weald was acting, as Everitt claimed for Kent, ${ }^{45}$ as common pasture for the kingdom as a whole. It is similarly probable that by the 7th and 8th centuries, communities in more 'favourable' pays (from the French term for regions with shared physical, cultural and social settings) were beginning to create independent detached woodland pastures within the forest. These areas may once have been largely used for the seasonal pannage of swine, however, after the Conquest a shift towards cattle and sheep would have been the norm. ${ }^{46}$ These 'dens', as the pastures have come to be called, were likely first established by communities within an 'inter-commoned' area, however, after the 8th century, following the granting of land parcels, a distinction occurred with the resultant areas forming 'sub-commons' belonging to individual estates. These were further divided up until the 11th century to create 'manorial dens' ${ }^{47}$

A similar process is likely for the Kingdom of Sussex. Though Old English denn names are uncommon in the Sussex Weald it is likely that the fold names of the region denote directly comparable outlying pastures. ${ }^{48}$ This model was largely based upon parent settlements located on the more agriculturally favourable soils of the South Downs, Greensand Ridge or Coastal Plain. These pays bear a direct resemblance to so called 'original lands' in Kent ${ }^{49}$ and were linked by a system of transhumance and droveways to their accompanying seasonal outliers in the Weald. ${ }^{50}$

\section{ARCHAEOLOGICAL RESULTS}

The excavation area was located within an oval enclosure of ancient origin - the Hayworth - postulated by local historian Heather Warne ${ }^{51}$ to be part of the holdings of Earl Godwin during the late-Saxon period. It is likely that the site existed within a unit of farmed land by the reign of Edward the Confessor (AD 1042-66 ${ }^{52}$ ) and the boundaries of this oval can easily be traced on Nicholas Hardham's estate map of 1638 (Fig 3). The lanes which encircle 'the Hayworthe' are here named 'Halfe Streete' and 'Kinges Highwaye' and would have been little changed from the late medieval period. The lane which marks the oval's southern boundary also serves to separate the parishes of Cuckfield and Keymer, a detail that further corroborates the enclosure's antiquity.

The fieldwork took place within an area of rough grassland on a south facing slope bounded by mature hedgerows and woods. The underlying geology comprises Upper Tunbridge Wells Sand and Clays..$^{53}$ The southern boundary, which was marked by the Henfield Wood Fault, occupied a band of Grinstead Clay and Cuckfield Stone. A landscape feature identified as a silted-up water course was investigated via geoarchaeological sampling.

The archaeological investigations revealed the top of underlying clays at between 0.20 and $0.60 \mathrm{~m}$ below the existing ground level. Within the excavation area an outcrop of 
weathered sandstone was encountered. The natural horizon was sealed beneath top/ploughsoil and subsoil deposits, as well as colluvium on the dip-slope. Overall, modern disturbance to the archaeological features was negligible, however, the insertion of 19thcentury land drains, together with ploughing activity and roots all served to truncate the remains to some degree.

Apart from the pollen record, residual early prehistoric flintwork and late IronAge/early Romano-British pottery, the majority of the archaeological activity was medieval in origin and dated between the 11th and 13th centuries. Very little evidence of any subsequent medieval activity was encountered; only a single sherd of 14th-century pottery was recovered from the topsoil. The Hayworth may have seen a contraction in exploitation at this time due to economic changes and depravations as a result of the Black Death, cattle murrain and climate change of the first half of the 14th century.

\section{THE 7TH- TO 11TH-CENTURY TOPONYMIC EVIDENCE}

As mentioned previously, place-names incorporating Old English elements have the potential to illuminate Anglo-Saxon settlement and land-use. Figure 4 shows the likely extent of the manor of Trubwick alongside what would later become the freeholds (and in the case of Hayworth and Bolnore, 'manors') that descended from this territory. What follows is an exploration of the particular place-names associated with Trubwick. These are indicative of how the land parcels were viewed by those naming them during the AngloSaxon period. This is discussed alongside evidence for the particular land-use elements from which these names were derived. This analysis combined with limited paleoenvironmental evidence is used here to characterise the Anglo-Saxon landscape context prior to the later medieval activity which would take place at the site.

Trubwick itself (Trubewica AD 1166, Trubwic AD 1199) probably derives from an amalgamation of an Old English personal name Trubba (a possible pet form of Trumbeorht or Trumbeald) and the element wic. ${ }^{54}$ Old English wic has been variously interpreted as 'a dwelling, a building or collection of buildings for special purposes, a farm, a dairy farm', and it seems that the specialised purposes could include manufacture, salt production and coastal trade ${ }^{55}$ as well as farming. ${ }^{56}$ Perhaps the most significant connotation of the name in a Wealden context is that concerned with dairying. This could be associated with the pasturing and milking of sheep ${ }^{57}$ or with cows, as on the Downs of Kent. ${ }^{58}$

Haywards (Heyworth AD 1261, Hayworth(e) AD 1276) is a compound of Old English word ('an enclosure') and hege ('a hedge, a fence') or hēg ('hay, mowing grass'). ${ }^{59}$ The name essentially means hedged enclosure ${ }^{60}$ and therefore consideration of the similar element haga is prudent. This may derive from the same Primitive Germanic root word as hege, ${ }^{61}$ and has been well studied by Hooke ${ }^{62}$, who has viewed these names as a strongly fenced enclosures, enclosed woods often with royal associations, early game preserves (AngloSaxon 'proto-parks'?) or even fortified settlements. ${ }^{63}$ These connotations are seen by Everitt as unlikely for a Wealden context - the names being a more likely reference to enclosed pasture with the word element perhaps indicating an enclosure for stock. ${ }^{64}$ To Faith $^{65}$ the 'worthys' of Devon (derived from name elements related to worð) were an early and distinctive type of farm, distinguished by curving boundary banks and apparently established in uncontested 'open' landscapes. They formed a sub-set of what Roberts and Wrathmell called 'oval enclosures'. ${ }^{66}$

The final two names associated with the territory of Trubwick are Bolnore (Bulnore AD 1559) and Wigperry (Wyggepyrye AD 1296, Wygepirie AD 1298). The former contains the 
Old English element ōra, which is understood to mean 'a border, a margin, a bank, an edge $^{\prime 67}$ and often occupied areas in the landscape which acted as markers for travellers. ${ }^{68}$ The name may show that a dairy farm at Trubwick was associated with cattle as it could be derived from 'bull's bank' or possibly from an Old English personal name, ie Bula. ${ }^{69}$ It would be easy to imagine how the sloping ridge to which the name is tied would be recognisable by its grazing herds to those travelling on the myriad local droveways or the nearby Roman road the London to Brighton Way. Wigperry may mean Wicga's pear tree ${ }^{70}$ or, although less likely, 'pear tree of the wic'. $^{71}$

\section{THE 7TH-TO 11TH-CENTURY HISTORIC LANDSCAPE EVIDENCE}

Trubwick is known to be a detached Wealden outlier of the manor of Plumpton/Plumpton Boscage. ${ }^{72}$ As such, Trubwick would have operated within the system of seasonal transhumance known to be prevalent within the Weald during the Anglo-Saxon period. The date to which the system of out pasture derives is not entirely understood and has been recognised as an important area for further study. The Hayworth's nature as one of these detached seasonal pastures, similar to the Kentish 'dens' described above, indicates that it would have been linked to its parent settlement by a droveway. A candidate for this route can be found in an existing sunken lane which passes close to the south and west of the site. This feature, as acknowledged above, is named as 'Halfe Streete' and 'Kinges Highwaye' in 1638 (Fig 3). The lanes northern projection as it turns towards Cuckfield did not survive as a bounded feature in the early 17th century, however, its line is possibly preserved in a boundary shown on the OS $1^{\text {st }}$ Edition map (1896). The lane would have served as the Hayworth's western extent and separated this holding from the territory of Bolnore beyond. Further trackways and hedges on the northern and eastern sides indicate an oval shaped enclosure adjacent to the open 'Haywards Heath'. The definition of a Kings highway was largely a 12 th-century construct, ${ }^{73}$ but the term could conceivably be applied to an earlier road. Two documents referring to a Kings Highway at Plumpton dated 1639 and 1739 respectively ${ }^{74}$ may suggest the route of the current B2112 and Plumpton Lane as the most likely course linking the parent (Plumpton) with its Wealden outlier (Trubwick) (Fig 5).

Whatever the date of Wealden droveway creation ${ }^{75}$ it is clear that they may have had an influence over patterns of boundaries and land-use in the areas in which they existed. Indeed, the modern road networks as well as the medieval and post-medieval parochial, manorial and settlement patterns of the Weald owe much to the existence of the droves, ${ }^{76}$ a fact that makes them of key importance in understanding the history of the evolution of settlement in south-east England as a whole.

The three later freeholds of Hayworth, Bolnore and Wigperry, were probably not the only areas of land that belonged to the later medieval manor of Trubwick which clearly had its origins in the Anglo-Saxon period. Areas of waste recorded on Nicholas Hardhams map were also likely parts of the manor. The waste of Trubwick was described as an elongated area of predominantly roadside waste which may relate to the trackway north of the Hayworth as well as the funnel-like feature shown on Figure 4. This area of waste was said to end at the Hatchgate, ${ }^{77}$ the name of which comprises two elements which have been frequently linked with droveways and pastoral activity. ${ }^{78}$ The 'Hatchgate' name is preserved in a modern farm. The waste of 'Haywards Hoth' is also recorded, and would have been utilised as an area of unenclosed pasture where the lords of Trubwick had rights of common. ${ }^{79}$ 
As well as droveways and areas of waste, another feature of the Sussex Weald is clear 'arc-shaped', or sub-oval boundaries of which the Hayworth and Bolnore appear to be examples. This category of enclosure are generally surrounded by roads and tracks aligned in a similar direction and bear a resemblance to, but have no evidence of being, medieval parks. ${ }^{80}$ They often become tenurially distinct by the late medieval period and have been shown to share a distribution which correlates with that of the Saxon fold names of the region. ${ }^{81}$ These fold place-names largely exist in the north-western Sussex Weald and across the border with Surrey, however, there is also an area to the south of St Leonard's Forest in which fold occurrences also exist. ${ }^{82}$ This area shares some landscape characteristics with the north-western Sussex Weald as does the immediate area of the site itself, which lies on the north-eastern edge of this zone.

\section{PERIOD 1, PHASE 1: 11TH CENTURY (FIG 6)}

Following the Norman Conquest, the Manor of Plumpton as well as much of the land in the vicinity of the site was given to William Warrenne (Lord of the Rape of Lewes). The first recorded instances of the Warennes' influence in the area relates to the granting of the parish church of Cuckfield to Lewes Priory in AD 1091-8. ${ }^{83}$ Fieldwork showed that during the same century the site comprised two open areas (OA1 and OA2; probably utilised as pasture or wood-pasture) divided by a stream. Ditches of a driftway or track (GP 3; R1) were encountered projecting into an area north of the watercourse (WW1). These were of similar dimensions and were filled by comparable deposits, however, only the southerly of the two contained dating material (nine sherds of pottery). This feature, like its counterpart, continued beyond the western limit of the excavation probably linking with the adjacent droveway - 'Halfe Streete Lane'.

The watercourse (WW1) was sampled for pollen analysis and radiocarbon dating. ${ }^{84} \mathrm{It}$ was filled by an organic sandy silt, which in turn was overlain by a mottled silt clay alluvium. The organic component was well broken down and as a result only a bulk sediment sample and a piece of charcoal were suitable for radiocarbon dating. The condition of the pollen and the weakly laminated structure of the sediment suggested the deposit had formed under still or slow flowing water conditions. The minerogenic component comprised fine sand indicating influxes of sediment, possible as surface run-off from cleared land. The dating suggests accumulation was occurring between AD 658-1028, at least at the location sampled (sediment, SUERC 47390, 1370+26 cal BP, 95.4\% AD 658-725 and $A D$ 738-772; charcoal, SUERC 47391, 1046+26 cal BP, 95.4\% AD 899-919 and AD 963-1028). Deeper deposits may be present within the channel but were not accessible.

PERIOD 1, PHASE 2: 12TH CENTURY (FIGS 7-8)

During the 12th century there was a significant increase in activity. This related predominantly to the creation of a farmstead which included features related to livestock management, the erection of buildings and features related to drainage and enclosure. The 11th-century 'open' or wood pasture, north of the watercourse, was converted into a field system (FS1) by means of a roughly N-S orientated ditch and associated fence line (GPs 4 and 5 respectively). Though the field-scape within the enclosure of the Hayworth may be of earlier inception it is not until the 12th century that any tangible evidence of internal land division is recognised.

FS1 was orientated in relation to two parallel curvilinear ditches with associated fence lines (GP 6; R2). The ditches were accompanied by postholes along their length and 
had gradually sloping sides with rounded bases. Finds of 12th-century pottery were produced from the fill deposits of both ditches, however, pottery from the outermost ditch spanned a slightly later date range. The ditch also showed some evidence of recutting in the 13th century (see D2 below). The feature was interpreted as a driftway or cattle race presumably associated with the droveway to the west of the site. A livestock sorter was evidenced by a substantial, centrally placed posthole within the eastern end of the route (GP 10). The narrowing to the south-east of this feature (although obscured by later recutting) may be interpreted as a cattle crush. Comparisons with modern cattle races show a curving route as beneficial to controlled and safe livestock movement and both the race and the crush have similar dimensions to the medieval example found here.

A ditched division on the western side of the site (D1) separated a holding area or pound (OA4; probably associated with the adjacent Kings Highway) from the central open area of the farm complex. A gap along the length of the ditch allowed access between the two areas. Two shallow features on the western side of the ditch were interpreted as treethrows and may indicate a hedge on this side. This would have further aided separation between holding areas (OAs) 3 and 4. The ditch itself (GP 11) was clearly intended to drain R2 downslope. This drainage capability allowed the insertion of a small waterhole (GP 13) that silted contemporaneously with the ditch and probably acted as a medieval form of livestock trough. The majority of the pottery from the ditched division D1 consisted of flint and sandy ware cooking pots, one with a hollow-topped rim. There were also a few flintonly tempered sherds and three tempered with coarse sand, suggesting final deposition toward the end of the 12th century. As well as pottery the waterhole produced a whetstone, in a local fine Wealden sandstone, of pale grey colouration. The squaresectioned elongated form of this stone is typical of local products.

The remains of a large building were recorded in the northern part of the site (B1). This structure was clearly sited as the main focus of the farmstead and was positioned to take advantage of the free draining and hardstanding properties of an underlying sandstone outcrop. The building was of two parts separated by a partition (GP 19) and was comprised of three lengths of foundation cut for sill walls, often terminating in substantial postholes (GP 18). The linear structural cuts were situated to create the N, E and W sides of a building. A lack of similar structural evidence on the southern side is thought to represent absence rather than truncation, probably indicating an open front. Fragmentary remains of possible drystone sill walls were encountered in the base of some of the structural cuts, and pottery of 12th- and 13th-century date was retrieved from their fills.

Internal features in the structure were confined to the eastern half and comprised two postholes (GP 20) and post pads (GP 21). The postholes had comparable fills to those found in line with the outer walls and the post pads were formed of local Wealden sandstone probably acquired close to the site. Rough splitting of the stone indicated their use in construction. Postholes on the southern side of the building may comprise the remains of uprights within an open frontage (GP 22).

A further group of postholes (GP 23) encountered to the south of the building are thought to represent a fenced exterior 'straw yard' (ENC1). These were fairly large in size and were filled with similar deposits of mid-dark yellow brown silt clay that contained finds of fine flinty, or flint and sand tempered wares, as well as fragments of sandstone (probably utilised as packing material). A possible redeposited post pad was encountered within one of the postholes. 
The evidence for a second 12th-century building comprised a rectangular space devoid of features apart from a disturbed deposit of sandstone construction materials (BP1). The building plot was defined by ditches (GP 15) possibly once open on the eastern side. It is presumed that little below ground evidence of the building existed and that it was largely built upon (dry) sandstone sill walls. Finds collected from the ditches forming the enclosure included 102 sherds derived from 20 different cooking pots and a single lamp. The cooking pot rims included thickened everted, beaded and hollow-topped types of the second half of the 12th century. The presence of the pottery, lamp and cooking waste indicate that the building plot comprised a dwelling. Small quantities of medieval peg tiles recovered from a nearby 12 th-century refuse layer are thought to have derived from the surrounding to a smoke-hole, rather than providing evidence of the building's main roofing material. The structure and surrounding ditches fell out of use before the end of the 12th century.

A number of fenced ditches clearly compartmentalised the area to the south into small fields sloping downhill to the adjacent stream (GP's 25-28; FS2). The compartments are most likely associated with drainage and stock separation. One of the ditches (GP 26) produced a fragment of circular grindstone, c $360 \mathrm{~mm}$ in diameter. It is likely to have been used for the sharpening of blades or tools. The 138 pottery sherds from these ditches represent at least 56 different cooking pots and suggest they were active throughout the 12th century. A short right-angled length of ditch together with a posthole (GP 33), were interpreted as an animal pen (S1) within FS2.

One compartment within the ditch system (OA5) included evidence of two charcoal clamps (GP 24). The larger of the two features comprised a shallow pit with stake and postholes. These were all filled with highly concentrated, often large, charred wood fragments, consistent with the industry and presumably relate to an extraction pit to gather the turf and clay necessary to seal the clamp, as well as posts for structural integrity and removal during lighting. The charcoal was predominantly mature wood of oak and beech, rather than roundwood from coppiced woodland. This suggests that timber of these taxa grew widely in the surrounding landscape and were selected due to their suitability for charcoal production. One of the clamps produced a handle fragment from a scale tanged knife. Remains of bone or wood scales were attached to the knife with three metal rivets. A small section of the iron blade was preserved in the corrosion product which also contained evidence of a possible leather sheath or scabbard. The object was recovered from silting of a hollow caused by the clamp during the features disuse. Scale tang manufacture is largely a 14th-century introduction. ${ }^{85}$

A single pollen sample ${ }^{86}$ was recovered from a layer of 12th-century refuse and redeposited natural within the watercourse (WW1). This material was charcoal rich and suggests a period of ground consolidation achieved by depositing waste material and clay within what would have been the almost infilled stream channel. It may relate to an attempt to ford the watercourse or create a gentle, safe incline for livestock. The pollen indicated a range of taxa including wetland tree species and cereal pollen.

\section{PERIOD 1, PHASE 3: 13TH CENTURY (FIGS 9-10)}

It is largely in the 13th century when documentary evidence relating to the immediate environs of the site either begins to be produced or survives. This is during a time when Peter Brandon, has gone as far as to state that, 'a more unpromising environment for economic development in the 13th and early 14th centuries than the Weald would be hard to find in lowland England'. ${ }^{87}$ Against this backdrop of agricultural toil 
in a discouraging setting we first learn of a John de Trobewyk who was holding a messuage and land in 'Trobewyk and Haywothe' in $1276 .{ }^{88}$ A Philip of Hayworth is cited in 1265 and a Thomas of Eywrth in 1266, as suitors to the Barony of Lewes Court. Philip is mentioned along with a John of Bolenhore as 'pledges' for a William Winkpirie in relation to a court summons. ${ }^{89}$ As suitors to the court, the summoned parties may be viewed as neighbours and freeholders whose lands (Hayworth, Bolnore and Wigperry) would have formed the major landholdings of the manor of Trubwick. ${ }^{90}$ The Trubwick and Hayworth families are mentioned in documentary evidence throughout the 13th century. The Trubwicks represented the overlords of the manor, with the Hayworth's as freeholders. By the mid14th century, however (AD 1358), only the Hayworths' are named in accounts, the manor of Trubwick having fallen into their possession. ${ }^{91}$

The 13th century is largely a story of adaptation of the existing farmstead. Ditches were remodelled or fell out of use and new buildings and enclosures were laid out. It is probable that the field scape of the Hayworth created in the preceding phase (or earlier) continued in use during the 13th century, attested by a small number of 13th-century sherds of sand tempered cooking pot from one of the associated ditches (GP 26). During this phase, remodelling of the 12th-century driftway (R2) took place. Significant recutting of the outermost ditch (GP 6) occurred along its central portion, converting this feature into a fenced enclosure for the farmyard (D2; GP 34). Sherds of 13th-century pottery associated with this ditch were from a mixture of 13 different cooking pots and a sparsely green glazed sand tempered jug.

The main 12th-century area of the farm complex (OA4) was significantly expanded and earlier ditches were decommissioned. Dwelling (BP1) went out of use and was replaced by a new structure (B2; see below). The larger (open fronted) building (B1) continued in use, although there is a possibility that the eastern half of the structure may have fallen into disrepair by the 13th century. A gully and possible posthole (GP 46) may have been related to 13th-century repair or extension of the structure or perhaps was derived from erosion backfilled with domestic waste. A pit (part of GP 40) situated close to the building contained fragmented cattle teeth as well as charcoal flecks, fired clay and 13th-century pottery.

Two deep postholes or pits (GP 47) truncated the earlier remains of the central partition (GP 19). These features were roughly $1 \mathrm{~m}$ in diameter at the top, with a depth of $1.2 \mathrm{~m}$. They had sharply sloping near vertical sides and flat bases. Both were cut into the sandstone bedrock and seemed to have been deliberately backfilled with deposits containing sandstone fragments, charcoal flecks and pieces of burnt clay. Finds produced from these deposits included 13th-century pottery, three unclenched iron horse shoe nails of the 'fiddle-key' type and a whetstone. If the features related to postholes they may be interpreted as substantial repair of the central partition, however, it may be more likely that they were pits utilised for a specialised function such as storage, perhaps for dairy produce.

Over 100 sherds of pottery were recovered from 13th-century deposits associated with the building. These represent 46 different cooking pots, but not a single jug was apparent, though one fine sand tempered ware could be from such a vessel. It is clear from the presence of 12th-century flint and shell tempered fabrics that residual material, probably associated with the earlier use of the building, is present within the combined assemblage, however, the sherds of 18 different sand-tempered cooking pots clearly signal the presence of 13th-century refuse.

Overlying the infilled southerly driftway ditch of $\mathrm{R} 2$, was a large sandstone and clay hearth (GP 35). Much in situ burning was recorded and the underlying clay was fire- 
reddened but produced little charcoal or charred macrobotanicals. Some 13th-century pottery and a single spherical hammerscale were collected from the fabric of the hearth along with chunks of fired clay and pieces of briquetage. Situated to the north of this feature was a group of postholes (GP 36), these contained sandstone post packing but no dating evidence. They are thought to be the partial remains of a structure associated with the hearth (B2). Similar evidence on the southern side was largely missing due to truncation.

A roughly N/S beam or sill slot (GP 38) that terminated in postholes formed the eastern side of the building. This was partially overlain by deposits of mid yellow brown silt clay (GP 39) that produced finds of 13th-century pottery. This layer is thought to relate to an area of trample or poaching perhaps within an entrance to B2. Two areas of fire reddened clay (GP 37) investigated in proximity are thought to be related to the buildings destruction by fire or some other related in situ burning event. The presence of residual 12th-century pottery within features related to the building may indicate that it was constructed in the later years of the preceding phase.

An enclosure (ENC2) was situated in the SE corner of the farmyard (OA4). A gap between ditches of D2 and FS2 would have acted as access from the field system to the east (FS1). The enclosure was dominated by a thick layer of livestock poaching and overlying destruction deposits (GP 45). The remains of truncated postholes (GP 44) and a drain gully (GP 42) indicate the location of a fenced yard, animal shelter or possible dwelling. This was bounded by an enclosure ditch (GP 43) separating it from the main farmyard (ENC2 and OA4). Medieval horseshoe fragments, horse teeth, whetstones and a large group of 13thcentury pottery found in the vicinity of the enclosure may give some indication of associated activity. Interestingly, the vessel total included sherds from up to four different fine sandy jugs, by far the highest number from any pottery grouping on site.

The depositional processes at work in the southern half of the site changed during this phase to that of colluvial accumulation $\left(W W 1^{92}\right)$. The pollen indicates a more open grassland landscape at this stage, with occurrences of weeds and cereal pollen in the record. The stratigraphic relationship coupled with the pollen suggests this deposit began accumulating after the 12th century, although the precise timing is unclear. The minerogenic nature of the colluvium is probably due to overall clearance of woodland in the immediate vicinity of the site causing destabilisation of hillslope soils.

\section{DISCUSSION}

\section{TH- TO 11TH-CENTURY SEASONAL PASTURE}

Together, archaeological and place-name evidence suggests a seasonal pasture existed here in the Anglo-Saxon period from the 7th to 11th centuries. This appears to have comprised twin oval enclosures (the Hayworth and Bolnore) associated with a large area of open grazing (Haywards Heath). Knowledge of Wealden development gained through the work of landscape historians ${ }^{93}$ shows the region would have originally been intercommoned, however, by the 8th century when the Hayworth began to be cleared, 'sub-commons' belonging to individual estates were being created. This process, which has been further developed by Fox ${ }^{94}$ for 'wold/wald' landscapes, accords well with the early landscape changes encountered at the site. It appears that the oval enclosure of the Hayworth was progressively (but only partially) cleared of woodland from the mid-late Anglo-Saxon period creating an environment in which beech with oak had become the co- 
dominant woodland species. By the onset of the 12th and 13th century, the presence of grassland and cereal pollen suggests a move to a more open, cultivated landscape.

Warne ${ }^{95}$ has convincingly identified the Hayworth as being part of the holdings of Godwin, Earl of Wessex and father to Harold Godwinson the last Anglo-Saxon king of England during the 11th century. It seems possible therefore that archaeological remains associated with Period 1.1 originated in the late Anglo-Saxon period, and were related to seasonal woodland and/or pastoral exploitation under one of England's most prominent families. This was during a stage of Wealden settlement evolution when the older commons were being subdivided to create 'manorial dens' ${ }^{96}$ The, albeit sparse, 11th-century evidence may attest to seasonal usage with herders taking their stock to a well-watered and enclosed pastoral reserve.

The Old English toponymic evidence associated with the site indicates that AngloSaxon usage was mainly concerned with the pasturing of cattle. The name element wic associated with Trubwick ${ }^{97}$ and possibly, but less likely, Wigperry ${ }^{98}$ suggest a dairy farm. ${ }^{99}$ Though Anglo-Saxon dairying often involved sheep, it is possible that the area surrounding the site was recognisable for the pasturing of bovines, implied by the place-name Bolnore (see above). That this husbandry was connected to a hedged oval enclosure similar to the 'worthys' described by Faith ${ }^{100}$ and highlighted in Somerset by Stephen Rippon and Michael Costen ${ }^{101}$ is striking, and this land parcel may represent an early intake from the Wealden forest in much the same way as similar features were 'inned' from marshlands. ${ }^{102}$

Analysis of the 11th-century pottery assemblage may, however, suggest that the earliest features at the site might be more representative of the beginnings of Norman exploitation (under the Warennes') rather than an inherited Anglo-Saxon outlying pastoral system. The majority of pottery encountered throughout Phase 1.1, is more indicative of a post-Conquest date, suggesting perhaps an intensification of activity as Anglo-Saxon models were exploited via Norman feudal land stewardship. Indeed, some 11th-century pottery was residual in 12th- and 13th-century features supporting 11th-century origins for the farm complex. The Hayworth at this time seems to have comprised a peripheral unit of farmed land, predating the nucleated village and parochial centre of Cuckfield built to serve it and other outlying farms. Such parish edge settlements have been linked to the ancient pastoral origins of Anglo-Saxon and earlier Wealden colonisation, ${ }^{103}$ and in the Hayworth we have the indirect ancestor of the post-medieval town of Haywards Heath.

\section{IDENTIFICATION AND EXPLORATION OF A 12TH- AND 13TH-CENTURY VACCARY}

Increased activity at the site during the 12th and 13th centuries, which have long been considered a period of economic advancement and agricultural innovation, ${ }^{104}$ surely corresponds to the creation of a farmstead related to livestock management. The main components comprised buildings and a droveway with associated enclosures. The intensification of activity is consistent with the prevailing view of the wider Weald at this time. Brandon for example states that from the 12th century, a marked population increase occurs in the Sussex landscape. ${ }^{105}$ The largest building is interpreted as an open fronted structure built on drystone sill walls with upright posts along at least part of the open front. This structure, is long (up to $34 \mathrm{~m}$ ) and narrow, facing south onto a fenced yard. The buildings size was facilitated by the 13th-century innovation of building on drystone sill walls which permitted (in areas where suitable stone existed) far more substantial buildings to be constructed than earth fast posts had allowed. ${ }^{106}$ Few similar structures have so far been excavated in south-eastern England, let alone the Weald. Due to the open frontage of the 
building, the unsuitability of local soils and the clear pastoral bias of the excavated features, the building is interpreted as an open fronted animal shelter. The remaining buildings may relate to an attendant herd-keepers dwelling or in the case of B2 perhaps a detached kitchen, dairy, or industrial area.

Few contemporary rural sites have been excavated in the region and none in the local area. The nearest comparable site of a similar date, Faulkners Farm, Hartfield, revealed that a part dairy economy was in operation there. ${ }^{107}$ When considering the farming economy practised at this site, many factors were taken into consideration. As well as a scale tanged knife, excavations produced a fairly large assemblage of sharpening tools, including at least five whetstones and a fragment of grindstone. The proportionally large quantity of these tool types perhaps indicates some kind of specialised function. A need to keep tools such as sickles and scythes sharp would be desirable in an arable based economy, however, although charred wheat and barley grains were present in small quantities, the unsuitability of the local soils for medieval grain production as well as the absence of quern fragments (which are common finds on medieval rural settlements) suggests that a predominantly arable economy is unlikely.

Interpretation of features as enclosures, animal pens, a driftway and waterholes suggest an economy based on livestock. This may account for the siting of the farmstead on a S facing slope, close to a recognised drove route (Kinges Highway/Halfe Street Lane) and water supply. Only limited faunal remains survived to indicate the type of livestock kept, the acidic clays of the Weald being non-conducive to the preservation of bone. Some horse and cattle teeth were found close to the animal shelter and although this confirms the occurrence of these species on site, the quantity is not adequate to suggest economy. The inland presence of briquetage (from B2 and WW1) could indicate utilisation as salt licks for stock $^{108}$ or perhaps additional processing to incorporate the resultant salt in dairy production (ie butter and cheese). ${ }^{109} \mathrm{~A}$ degree of woodsman ship is recognised as a necessity for anyone attempting to agriculturally exploit the Weald. The dominance of sharpening tools among the finds assemblage, together with the wooded nature of the local environment, indicates that those working and maintaining the land were familiar with managing the woodland resource. Even the masonry and whetstones recovered were manufactured from local Wealden sandstones, perhaps quarried close by.

This rather regionally restricted view of resources, which may be a feature of the remoteness of 'wold/wald' communities in general, ${ }^{110}$ is also reflected in the pottery assemblage which failed to suggest far ranging contacts. It is probable that trade in day-today goods was generally conducted with communities in adjoining valleys. That is not to say that the people concerned did not have access to at least some degree of distance infrastructure. The bounds of the unit of farmland in which the site is a component 'The Hayworthe' are to the south and west the 'Kinges Highwaye' and 'Halfe Streete'. These form the routeways to the parent manor of Plumpton (and possibly the rapal centre of Lewes in the south-east) as well as to the parish centre of Cuckfield and its associated common in the north-west (Fig 11). These tracks and in particular, the funnel shaped arrangements on the north-western extents, display the classic form of droveways and funnels associated with the movement of livestock to and from common. ${ }^{111}$

During the 12th and 13th centuries England witnessed the development of the great sheep and cattle ranches the beccarie and vaccariae so prevalent in contemporary documentation. ${ }^{112}$ It is largely in the north of England that complexes of buildings and enclosures for stock management, both for sheep and cattle have so far been identified. The 
dominant feature of beccary sites are the earthwork foundations of long buildings. ${ }^{113}$ Vaccary sites have so far yielded little evidence of built fabric, ${ }^{114}$ although this may be the result of a lack of fieldwork and preservation. Limited excavations of beccary sites have shown buildings to vary in length between $23-65 \mathrm{~m}$ and of between 6-8 $\mathrm{m}$ in width. ${ }^{115} \mathrm{Few}$ beccary or vaccary sites have been identified by excavation in the south-east of England, however, medieval documentary evidence for both cow sheds and sheep houses does exist. ${ }^{116}$ Apart from a possible late-medieval timber-framed sheepcote in Hampshire ${ }^{117}$ (Fig 12) only earthwork evidence for these buildings remains. ${ }^{118}$

Though the length and open frontage of B1 made identification of the site as a beccary possible, a pastoral economy based on sheep farming is unlikely for the Hayworth. The claylands of the Weald have historically been seen as unsuitable for the grazing of this livestock type. A picture which is reflected in early 14th-century records for the Cuckfield parish where no instances of them being kept were documented. ${ }^{119}$ Medieval sheep rearing is far more often a feature of the southern downland and marshes. ${ }^{120}$ Cattle ranching and dairying are by far the more likely for this site.

Despite a lack of scholarly attention, vaccaries have been recorded in southern England since the time of the Domesday Survey when for instance three manors comprising vaccaria or wica were mentioned in the Vale of the White Horse (Berkshire/Oxfordshire border): 'At Sparsholt Henry de Ferrers has deprived the Crown of a dairy (vaccaria) producing six weys of cheese; at Shellingford the dues of cheese (consuetudines caseorum) are worth to Abingdon Abbey no less than $f 416 \mathrm{~s} 8 \mathrm{~d}$; at Buckland bishop Osbern has a dairy farm (wica) producing ten weys of cheese, which are worth $f 112 \mathrm{~s} 4 \mathrm{~d}^{\prime} .{ }^{121}$

Vaccaries have been recognised as an element in the pastoral usage of the Weald from Anglo-Saxon times, ${ }^{122}$ although systematic study of their presence has only recently been attempted. ${ }^{123}$ This is despite toponymic evidence from the Weald such as Chelwood Vachery near Ashdown Forest and Shere Vachery in Surrey, which provide instances of probable vaccary sites.

The principal building of vaccary enclosures must be viewed as the cowhouse. Documentary studies show these (like sheephouses) were of significant length; for example the structure recorded at Gatesgarth vaccary, Buttermere (built in AD 1282-3) measured $20.5 \mathrm{~m}$ long. ${ }^{124}$ These buildings and the area of hay meadow and/or woodland was surrounded by an enclosure (Middle English haya). ${ }^{125}$ This could be formed of a bank (often probably hedged) and ditch, or in stone using areas vaccary walls. The purpose of these enclosures was to accommodate the cattle overwinter as well as to protect winter fodder in the form of hay and browse. The areas of open grazing were intended as summer pasture and would be situated on poorer upland landscapes, often comprising areas of forest, chase and waste. ${ }^{126}$ The Hayworth may be so named due to the presence of a hedge ringing its perimeter. The presence of haw and blackthorn within the environmental assemblage and associations with the Old English name element haga might imply these species formed a thorny hedge, beneficial in controlling livestock and a discouragement to would-be thieves or wolves intent on preying on the herd.

The double oval field pattern indicated by the combination of the Bolnore oval together with the Hayworth itself (see Fig 4) can be compared with double oval field patterns associated with vaccaries in Lancashire noted by Mary Atkin. ${ }^{127}$ These sites also share a central watercourse which would have provided an important landscape feature for the watering of stock. 
Together the evidence presented here suggests that the remains encountered during the Bolnore Village development almost certainly relate to a rare example of a vaccary farm. As an outlier of the manor of Plumpton, Trubwick would prior to its subinfeudiation have been part of Earl Warrenes forest demesne. The Warrenes lands were known to be associated with vaccaries in Yorkshire where the manorial court rolls record:

And the officers of these vaccaries were called instauratores and did give their yearly accounts of the Revenues of the Cattell as the Graves did give of their rents at every Audicte to the Officers of the Earle Warrene. ${ }^{128}$

Though not a true 'upland' region on the scale of Yorkshire and the Pennines, the Weald was certainly considered a 'marginal' area in the medieval period. Indeed, it would be easy to perceive parts of its landscapes (such as Ashdown Forest) as functioning similarly to the moorland and fell of northern England. Like the vaccary lands of the north, the Weald was an area of dispersed settlement with a cultural history of seasonal exploitation. The manor of Trubwick shares remarkable similarities with the northern England vaccary sites. It clearly possesses the two major landscape elements required of such an establishment, that is an enclosed plot of wood and meadow namely the Hayworth and an expanse of open grazing on the neighbouring waste of Haywards Heath.

Only the manorial tenants of Trubwick were known to have the right to pasture animals on the wooded heath in $1567 .{ }^{129}$ Wyn Ford and Conway Gabe presumed that the pastured livestock would have been cattle, ${ }^{130}$ however, it is likely that this was not the only area of extensive grazing that the manor of Trubwick had access to. The stock funnels and droveways associated with the Hayworth potentially allowed the movement of cattle not only to the heath but also to areas of common and park in Cuckfield as well as to St Leonards and Ashdown Forests. These large areas of chase would have likely been exploited as summer agistment grounds and following payment of a fee the lords of Trubwick and Hayworth would have been able to graze their cattle. The landholders may have also been able to exercise common rights of pasture and herbage in these forests although no records of any such rights attached to Trubwick have been encountered. Cattle were being pastured in St Leonards Forest in the 13th century when tithes of herbage were mentioned in 1235 and tithes of calves and cheeses in $1247 .{ }^{131}$ The existence of agisted cattle on Ashdown Forest is recorded in a survey of $1273^{132}$ and their prevalence is also recorded at the end of the 13 th century when 2,000-3,000 cattle were grazed. ${ }^{133}$

At the Hayworth, the cluster of buildings encountered on the site may represent the dwelling of the herd keeper or vaccarii as well as the largest building, which probably relates to a cowhouse. The farmstead would have clearly been a specialised part of the Hayworth. John de Trobewyk was holding a messuage and land in 'Trobewyk and Haywothe ${ }^{\prime 134}$ at the time the site was in operation and it has been postulated by Warne that the manorial seat of Trubwick (and later the Hayworth) would have been situated at Great Haywards Farm. ${ }^{135}$ The small fields that represent an inner, oval core around this manorial seat (Figs 4 and 11) would have probably been utilised as the Hayworth's arable, meadow, gardens and convertible land. This may be where the small quantities of medieval cereal grains (including wheat, barley and possibly oat) present at the site were derived. The remaining areas outside of this 'infield' comprised a mixture of woodland, grassland pasture and wood-pasture, dominated by beech and oak, but with hedgerow species suggesting a more open habitat.

The interesting move towards a partially cleared wooded environment where beech became the dominant species seems to have been the result of a progressive 
landscape change from the 7th century. Not only does this suggest Anglo-Saxon and medieval development of early wooded environments (into landscapes more suitable for pastoral exploitation and therefore more permanent settlement) but also selection of tree species to aid the viability of these pastures. Acorns are known to be poisonous to cattle and a reduction in their numbers would obviously be beneficial on any pasture where cattle were kept. Beech foliage on the other hand can be an important fodder species especially when forming 'pollard hay' or as an early spring feed when grass is unavailable.

Whether the family of Hayworth would have been acting as the vaccarii of the manor (and thus living at the site) in the time of the Trubwicks overlordship is unknown but interesting. The 13th-century agricultural writer Walter of Henley records the office of Hayward as being responsible for the woods, corn and meadows of the manor ${ }^{136}$ they were also responsible for the fences and hedges of enclosures and for preventing cattle from straying. ${ }^{137}$ At this stage, the principal building on the site seems to have been a cowhouse. It was large, probably open fronted, but separated in two unequal halves by a partition. It is perhaps possible that one side of this building was for the housing of cattle and that the other comprised a store. The structural evidence within this latter half could be interpreted as relating to a second storey or mezzanine perhaps to act as a hay loft, although this interpretation remains unconfirmed. That medieval vaccary buildings were substantial affairs is suggested by a somewhat ambiguous reference to a mid-15th-century cowhouse in Marden, Kent:

The jurors state that Philippa of Hainault, formerly queen of England and lady of the manor of Milton Regis, and all previous lords of the manor and their tenants of the hundred of Marden should repair the house of a cow-pasture ('vaccaria'), called 'Cowhous' in the manor of Milton Regis. The tenants of Marden should repair the part called 'Somerhous' which is 18 feet wide and 48 feet long, and should make cheese, butter and dairy products for the serjeant ('serviens') called 'le day'. ${ }^{138}$

The building of a cowhouse was not an insubstantial cost in the early 13th century as the Winchester Pipe Rolls record: 'In quadam vaccaria de novo facta, 7s. 8d.'139 This is at a time when on the same estate the construction of a house would cost $5 \mathrm{~s}$ and $8 \mathrm{~d}$ : 'In I domo de novo facienda in curia, $5 \mathrm{~s} .8 \mathrm{~d} .{ }^{\prime 140}$ and a barn $14 \mathrm{~s} 8 \mathrm{~d}$ : 'In quadam grangia de novo facienda, 14s. $8 d^{\prime} .141$

\section{CONCLUSION}

Archaeological investigations have facilitated exploration of an area of woodland utilised under long-standing common rights, which evolved into a manorial holding held under rights of private property. Such transformations have been explored by Susan Oosthuizen ${ }^{142}$ and the results of work connected to the Hayworth may be important in this regard. It is arguable, however, when precisely the change occurred. What can be said with more confidence, is that landscape alterations experienced at the site ran concurrently with a period that is thought to be associated with the development of commons belonging to individual estates rather than so-called 'folk groups' of the South Saxon kingdom. As such, it is this time (approximately the 7th-11th centuries) when a change from 'common' to 'private' was occurring. The final move towards a 'Hayworth' held in severalty probably did not take place until the 12th century, a time by which a transition from 'seasonal' to 'permanent' was complete.

The site provided important paleoenvironmental remains and a rare Wealden pollen sequence for the Anglo-Saxon and medieval periods. Prehistoric woodland where 
oak, hazel and lime were the dominant species was replaced by a closed oak and hazel habitat where holly was part of the understory. This was gradually cleared from the 7th century $A D$, a process which began in what landscape historians have termed the "long 8th century', a period of social and agrarian innovation that lasted from the 7th to 9th centuries .${ }^{143}$ Landscape change continued until a 12th-century beech dominated, semi-wooded environment was achieved.

Woodland cover would further be largely denuded until the present day, however, the most notable formative clearances are attributable to the Anglo-Saxon period. This has important implications for our understanding of Wealden colonisation and clearance/reclearance of the region's woodland environment. This has often been attributed a mid-/late-Saxon date by landscape historians and although it is important not to generalise this does seem to be the case within the immediate vicinity of the site. Indeed, Everitt has claimed the 7th and 8th centuries to be the time at which parent communities were creating subordinate pastures within the Weald. ${ }^{144}$ In the case of the Hayworth Everitt's theory seems entirely plausible.

As well as aiding understanding of rural landscape evolution, the excavated features provide a rare if not unique insight into the likely form of 12th-and 13th-century cowhouses (ie similar to what is now termed an open fronted shelter shed). Chris Dyer's work in the mid 1980' ${ }^{145}$ suggested peasant buildings in the main ranged from $7.6 \mathrm{~m}$ to $15.2 \mathrm{~m}$ in length. Though more up-to-date statistics may exist, even the longest buildings Dyer analysed (which probably accommodated animals as well as people) only measured $18.3 \mathrm{~m}$ in length. The length of the structure excavated at the Hayworth is considerable by comparison perhaps indicating its status as a seigneurial building as opposed to that belonging to the servile tenantry.

Vaccaries could clearly exist within a lowland context, as well as in the usual upland landscapes in which they are usually recognised. As such, they may be viewed as a key element of land-use in areas of dispersed settlement such as the Weald. They are linked with the wic, and in this case word, place-names and the pastoral origins of colonisation within these 'marginal' lands. The Hayworth and vaccaries in general are connected to traditions of out pasture, transhumance and seasonal exploitation, as such they may be of importance in understanding the origins and development of medieval colonisation of marginal wooded areas. As an early oval enclosure the Hayworth is a primary feature in the contemporary historic landscape. It may have originated as an early medieval pound like enclosure at a stage when the Weald was acting as an extensive area of 'common' grazing. These oval enclosures have been considered crucial areas in which for fieldwork to take place and due to the work ventured here, a middle Anglo-Saxon date may be suggested for their creation and a specialised pastoral usage be given to their function. This theory, which may be corroborated by the similar Walkhampton Enclosure that at one time may have served as a horse stud, ${ }^{146}$ can only be confirmed with excavation of further examples; a research agenda that should be recognised for not just the Weald of southern England but for other so-called marginal areas around Europe that share a history of seasonal transhumance, detached outliers, a dispersed settlement pattern and oval landscape enclosures. 
ACKNOWLEDGEMENTS

Archaeology South-East would like to thank Crest Nicholson South Limited who commissioned the work, Luke Barber and Dr Rob Scaife for their help with specialist assessment, John Mills (West Sussex County Council) for his guidance throughout the project and Heather Warne for supplying a copy of the history of 'Hayworth and Trobewyk' . The Archaeology South East excavations were directed by Andrew Margetts, the fieldwork was managed by Neil Griffin, with editing and post-excavation work managed by Louise Rayner and Dan Swift. The publication figures were by Fiona Griffin and the reconstruction drawings are by the author. Thanks are due to David Martin for his comments on the reconstructions and to Professor Stephen Rippon (The University of Exeter) for his comments on an early draft of this paper. The author would also like to thank the anonymous referees whose observations he has sought to address, as well as all the archaeologists who worked on the excavations (especially Liz Chambers and Cameron Ross). The archive is currently housed with Archaeology South-East awaiting deposition at a suitable local repository.

\section{BIBLIOGRAPHY}

Atkin, M A 1985, 'Some settlement patterns in Lancashire', in D Hooke (ed), Medieval Villages: Review of Current Work, Oxford: Oxford University Committee for Archaeology Monogr 5, 171-86.

Atkin, M A 1993, 'Sillfield, Preston Patrick: a double-oval type of field pattern', Trans Cumberland Westmorland Antiq Archaeol Soc 93, 145-53.

Baildon, W P (ed), 1906, Court Rolls of the Manor of Wakefield, Vol II, 1297 to 1309, Yorkshire Archaeol Soc Record Series 36.

Banham, D and Faith, R 2014, Anglo-Saxon Farms and Farming, Oxford: Oxford University Press.

Barford, P M 1990, 'Briquetage finds from inland sites', in A J Fawn, K A Evans and I McMaster et al, The Red Hills of Essex: Salt making in antiquity, Colchester: Colchester Archaeol Group, 79-80.

Belloc, H 1909, On Everything, London: Methuen.

Biddick, K 1989, The Other Economy: Pastoral Husbandry on a Medieval Estate, Berkeley: University of California Press.

BL ADD MS no 5684, Dispute with the Barony of Lewes over common rights.

Brandon, P 1974, The Sussex Landscape, London: Hodder and Stoughton.

Brandon, P 1988, 'South-Eastern England', in H E Hallam (ed), The Agrarian History of England and Wales: Vol II, 1042-1350, Cambridge: Cambridge University Press, 312-25.

Brandon, P 2003, The Kent and Sussex Weald, Chichester: Phillimore and Co Ltd.

Brandon, P and Short, B 1990, The South East from AD 1000, London: Longman.

Bridbury, A R 1955, England and the Salt Trade in the Later Middle Ages, Oxford: Clarendon Press.

CCA DCc-ChAnt/M/244A, Mid-15th-century charter concerning the manor of Milton Regis.

Chatwin, D and Gardiner, M 2005, 'Rethinking the early medieval settlement of woodlands: evidence from the western Sussex Weald', Landscape Hist 27, 31-49.

Cooper, A 2000, 'The king's four highways: legal fiction meets fictional law', J Medieval Hist 26:4, 351-70. 
Coates, R 1999, 'Place-names before 1066', in K Leslie and B Short (eds), An Historical Atlas of Sussex, Chichester: Phillimore, 32-3.

Costen, M D 2011, Anglo-Saxon Somerset, Oxford: Oxbow.

Cowgill, J de Neergaard, M and Griffiths, N 1987, Knives and Scabbards, Medieval finds from excavations in London 1, Woodbridge, Suffolk: Boydell Press.

Ditchfield, P H and Page, W (eds) 1906, The Victoria County History of Berkshire Vol I, London: Archibald Constable and Company Ltd.

Dodgson, J 1978, 'Place-names in Sussex: the material for a new look', in P Brandon (ed), The South Saxons, Chichester: Phillimore, 54-88.

Dyer, C 1986, 'English peasant buildings in the later Middle Ages (1200-1500)', Medieval Archaeol 30, 19-45.

Dyer, C 1995, 'Sheepcotes: evidence for medieval sheepfarming', Medieval Archaeol 39, 136-64.

English, J 1997, 'A possible early Wealden settlement type', Medieval Set Res Group Annual Rep 12, 5-6.

English Heritage, 2006a, Historic Farmsteads, Preliminary Character Assessment: South East Region. Cheltenham: University of Gloucestershire in association with English Heritage and the Countryside Agency

English Heritage, 2006b, Historic Farmsteads, Preliminary Character Assessment: North East Region. Cheltenham: University of Gloucestershire in association with English Heritage and the Countryside Agency

ESRO SAS-N/217, Lease dated 12/10/1739.

Everitt, A 1986, Continuity and Colonization: The Evolution of Kentish Settlement, Leicester: Leicester University Press.

Faith, R 2006, 'Worthys and enclosures', Medieval Set Res Group Annual Rep 21, 9-14.

Faith, R and Fleming, A 2012, 'The Walkhampton enclosure (Devon)', Landscape Hist 33:2, 5-28.

Ford, W K and Gabe, A C 1981, The Metropolis of Mid-Sussex: A History of Haywards Heath, Haywards Heath: Charles Clark Ltd.

Fox, H 2000, 'The wolds before 1500', in J Thirsk (ed), The English Rural Landscape, Oxford: Oxford University Press, 50-61.

Fox, H 2012, Dartmoor's Alluring Uplands: Transhumance and Pastoral Management in the Middle Ages, Exeter: University of Exeter Press.

Gardiner, M 1999, 'The medieval rural economy and landscape', in K Leslie and B Short (eds), An Historical Atlas of Sussex, Chichester: Phillimore, 38-9.

Gelling, M and Cole, A 2000, The Landscape of Place-names, Stamford: Shaun Tyas.

Glover, J 1975, The Place Names of Sussex, London: B T Batsford.

Hanson, L and Wickham, C (eds) 2000, The Long Eighth Century: Production, Distribution and Demand, Leiden: Brill.

Hey, D 1996, The Oxford Companion to Local and Family History, Oxford: Oxford University Press.

Hodges, R 1982, Dark Age Economics: The Origins of Towns and Trade AD 600-1000, London: Duckworth.

Holgate, R 2003, 'Late glacial and post-glacial hunter-gatherers in Sussex', in D Rudling (ed), Archaeology of Sussex to AD 2000, King's Lynn: Heritage Marketing and Publications Ltd, 29-38. 
Holt, N R (ed) 1964, The Pipe Roll of the Bishop of Winchester 1210-11, Manchester: Manchester University Press.

Hooke, D 1989, 'Pre Conquest woodland: its distribution and usage', Agr Hist Rev 37, 11329.

Hudson, T P (ed) 1987, A History of the County of Sussex: Victoria County History Volume VI, part 3, London: Oxford University Press

Lamond, E (ed) 1890, Walter of Henley's Husbandry, London: Longmans Green and Co.

Lewis, E Roberts E V and Roberts K 1988, Medieval Hall Houses of the Winchester Area, Winchester: Winchester City Museum.

Margetts, A 2010, An Archaeological Evaluation at The Bolnore Village Development, Phase 4, Archaeol South E Report No 2010207-2138.

Margetts, A 2011, Post-Excavation Assessment and Updated Project Design Report, The Bolnore Village Development, Phase 4, Bolnore, Haywards Heath, West Sussex. Archaeol South E Report No 2011178.

Margetts, A in prep, The Wandering Herd: The Medieval Cattle Economy of the South-East, c 450-1450 (unpubl PhD, University of Exeter).

Mawer, A and Stenton, F M (eds) 1929, The Place-Names of Sussex: Part 1, Nottingham: Engl Place-Name Soc 6.

Mawer, A and Stenton, F M (eds) 1930, The Place-Names of Sussex: Part 2, Nottingham: Engl Place-Name Soc 7.

Newman, C 2006, 'Medieval period resource assessment', in M Brennand (ed), The Archaeology of North West England: An Archaeological Research Framework for the North West Region, CBA North West, 115-14.

Oosthuizen, S 2011, 'Archaeology, common rights, and the origins of Anglo-Saxon identity', Early Medieval Eur 19:2, 153-81.

Oosthuizen, S 2013, Tradition and Transformation in Anglo-Saxon England: Archaeology, Common Rights and Landscape, London: Bloomsbury Academic.

Pelham, R A 1934, 'The distribution of sheep in Sussex in the early fourteenth century', Sussex Archaeol Collect 75, 130-6.

Penn, R 1984, Portrait of Ashdown Forest, London: Robert Hale.

Roberts, B K and Wrathmell, S 2000, An Atlas of Rural Settlement in England, London: English Heritage.

Roberts, B K and Wrathmell, S 2002, Region and Place: A Study of English Rural Settlement, London: English Heritage.

Rippon, S 2000, The Transformation of Coastal Wetlands, Oxford: Oxford University Press.

Rippon, S 2002, 'Infield and Outfield: the early stages of marshland colonisation and the evolution of medieval field systems', in T Lane and J Coles (eds), Through wet and dry: essays in honour of David Hall, Sleaford and Exeter: Lincolnshire Archaeology and Heritage Report Series no. 5 and WARP Occasional Paper 17, 54-70.

Rippon, S 2008, Beyond the Medieval Village: The Diversification of Landscape Character in Southern Britain, Oxford: Oxford University Press.

Salzman, L F (ed) 1933, The Chartulary of the Priory of St Pancras of Lewes: Part 1, Sussex Rec Soc 38.

Salzman, L F (ed) 1940, A History of the County of Sussex: Victoria County History Volume VII, London: Oxford University Press

Smith, A H 1956a, English Place-Name Elements: Part 1, The Elements A-IW, Maps, Engl Place-Name Soc 25. 
Smith, A H 1956b, English Place-Name Elements: Part 2, The Elements JAFN-YTRI Index and Maps, Engl Place-Name Soc 26.

Taylor, A J (ed) 1940, Records of the Barony and Honour of the Rape of Lewes, Sussex Rec Soc 44.

Tebbutt, C F 1981, 'A Deserted Medieval Farm Settlement at Faulkner's Farm, Hartfield', Sussex Archaeol Collect 119, 107-16.

TNA SC 12/15/46, Survey Ashdown (Essedune) Forest dated 20/11/1273 - 19/11/1274

TNA Eccl 2-22-159-270B, Bishopric of Winchester Rent Rolls (superseded by Holt (ed) 1964).

Warne, H 2009, "Hayworthe" and "Trobewyk": An Assessment of the Early History of Hayworth and Trubwick in Haywards Heath, Haywards Heath: S Meier.

Watts, G 2003, 'Identifying drove roads in Southern England', Hampshire F Club Archaeol Soc 40, 18-19.

Winchester, A J L 2000, The Harvest of the Hills: Rural life in Northern England and the Scottish borders, 1400-1700, Edinburgh: Edinburgh University Press.

Winchester, A J L 2003, 'Demesne livestock farming in the Lake District: the vaccary at Gatesgarth, Buttermere, in the later thirteenth century', Trans Cumberland Westmorland Antiq Archaeol Soc 3, 109-18.

Winchester, A J L 2010, 'Vaccaries and Agistment: upland medieval forests as grazing grounds', in J Langton and G Jones (eds), Forests and Chases of Medieval England and Wales c 1000-c1500, Oxford: St John's College, 109-24.

Witney, K P 1976, The Jutish Forest: A Study of the Weald of Kent from 450 AD to 1380 AD, London: Athlone Press.

Worrall, S and Griffin, N 2004, An Archaeological Desk-Based Assessment and Walkover Survey of Land at Hayward's Heath, West Sussex, Archaeology South-East, August 2004. Archaeol South E Project 1876.

WSRO LYTTON/MSS/472, Feoffment dated 3/10/1639.

WSRO Add Ms 28, 784, Map Nicholas Hardham estate dated 1638.

Abbreviations

BGS British Geological Survey

BL ADD MS British Library Additional Manuscript

CCA Canterbury Cathedral Archives

ESRO East Sussex Record Office

TNA The National Archives

WSRO West Sussex Record Office

CAPTIONS

FIG 1

Site location plan showing area of archaeological investigations.

Drawing by F Griffin. (c) Archaeology South-East, UCL.

FIG 2

An example of the 'double oval' field pattern: from Tunley, Lancashire (after Atkins 1985, fig 12.2). Drawing by F Griffin. (C) Archaeology South-East, UCL.

FIG 3 
Nicholas Hardham Estate dated 1638 (WSRO Add Ms 28, 784).

FIG 4

Plan showing the likely extent of the Manor of Trubwick: and later freeholds and areas of 'waste'. Drawing by F Griffin. (C) Archaeology South-East, UCL

FIG 5

Plan showing the relationship between Trubwick and its parent Manor of Plumpton and the likely course of the attendant drove. Drawing by F Griffin. (C) Archaeology South-East, UCL

FIG 6

Period 1, phase 1 (11th century) plan of excavated features. Drawing by F Griffin. (C) Archaeology South-East, UCL.

FIG 7

Period 1, phase 2 (12th century) plan of excavated features. Drawing by F Griffin. (C) Archaeology South-East, UCL.

FIG 8

Period 1, phase 2 (12th century) reconstruction. Drawing by A Margetts.

FIG 9

Period 1, phase 3 (13th century) plan of excavated features. Drawing by F Griffin. (C) Archaeology South-East, UCL.

FIG 10

Period 1, phase 3 (13th century) reconstruction. Drawing by A Margetts.

FIG 11

Reconstruction of 'The Hayworth': looking north-east to Haywards Heath. Drawing by $A$ Margetts.

FIG 12

A possible sheephouse from mid-Hampshire. Reproduced from Medieval Hall Houses of the Winchester Area (1988) with permission of Elizabeth Lewis, Edward Roberts, Kenneth Roberts and Winchester City Council. Drawing by Nigel Fradgley.

\footnotetext{
${ }^{1}$ Archaeology South-East, Units 1 and 2, 2 Chapel Place, Portslade, East Sussex, BN41 1DR. a.margetts@ucl.ac.uk

${ }^{2}$ This work was undertaken by Archaeology South-East (UCL Institute of Archaeology) on behalf of their client Crest Nicholson (South) Ltd as a condition of planning in advance of a residential development linked to the new 'Bolnore Village' close to Haywards Heath, West Sussex.

${ }^{3}$ BL ADD.MS.5684.

${ }^{4}$ Salzman 1940, 159.

5 1986, 55.

${ }^{6}$ This article draws together the combined findings of a desk-based assessment (Worrall and Griffin 2004), an evaluation, watching brief and targeted excavation (Margetts 2010), and a post-excavation assessment
} 
(Margetts 2011). Archaeology South-East undertook the fieldwork between October and November 2010 (evaluation), and between January and March 2011 (excavation).

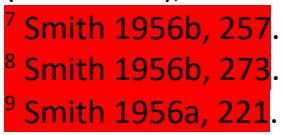

102000.

11 Rippon 2008.

121989.

132012.

14 Smith 1956a, 65.

15 Smith 1956b, 130

162014.

17 Eg Winchester 2000; 2010; Atkin 1985.

18 Fox 2012, 218.

191989.

20 Ibid, 16, fig 3.

21 Winchester 2010.

22 Winchester 2000, 69, 115.

${ }^{23}$ Newman 2006, 124-5.

24 Ibid 2006, 124.

${ }^{25}$ Winchester 2003, 114.

${ }^{26}$ Atkin 1993.

27 Atkin 1985, 173-5.

28 Atkin 1993.

29 Newman 2006, 124.

${ }^{30}$ Atkins 1985.

31 Winchester 2010, 115.

321909.

33 Holgate 2003, 30-1.

34 Roberts and Wrathmell 2000, 43-4.

35 1986, 42.

36 Ibid, 41-2.

37 Brandon 2003, 43-6.

38 Chatwin and Gardiner 2005, 45-6.

39 1986, 54-7.

40 Brandon 2003.

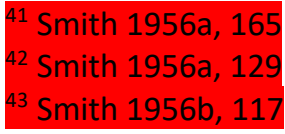

44 Mawer and Stenton 1929; Smith 1956a, 257; Dodgson 1978, 61.

45 1986, 54.

${ }^{46}$ Everitt 1986, 121-3.

47 Witney 1976, 78-103.

48 Brandon 2003, 45-6.

${ }^{49}$ Everitt 1986.

50 Brandon and Short 1990, 25-6.

512009.

52 Ibid.

53 BGS Sheet 302: Horsham

54 Mawer and Stenton 1929, 269.

55 See Hodges 1982, 47-86.

56 Smith 1956b, 257-63.

57 As on the Essex Marshes: Rippon 2000, 204.

58 Everitt 1986, 168.

59 Mawer and Stenton 1929, 268.

60 Smith 1956b, 274-5; Glover 1975, 74.

61 Smith 1956a, 221, 222. 
${ }^{62} 1989,123-5$.

${ }^{63} \mathrm{Ibid}$.

${ }^{64} 1986,142-3$.

${ }^{65} 2006$.

${ }^{66} 2002$.

\section{${ }^{67}$ Smith 1956b, 55}

${ }^{68}$ Gelling and Cole 2000, 203-5.

${ }^{69}$ Mawer and Stenton 1929, 262.

${ }^{70}$ Ibid, 269

${ }^{71}$ Warne 2009, 12.

${ }^{72}$ Salzman 1940, 159; Warne 2009.

${ }^{73}$ Cooper 2000.

${ }^{74}$ WSRO LYTTON/MSS/472; ESRO SAS-N/217.

${ }^{75}$ See Everitt 1986, 39; Chatwin and Gardiner 2005, 37-8.

${ }^{76}$ Everitt 1986, 38.

${ }_{77}$ WSRO Add Ms 28, 784.

${ }^{78}$ Everitt 1986, 130-1.

${ }^{79}$ BL ADD MS. 5684; Salzman 1940, 160.

${ }^{80}$ English 1997.

${ }^{81}$ Chatwin and Gardiner 2005.

82 Ibid.

${ }^{83}$ Salzman 1933, 15.

${ }^{84}$ Sample no $\langle 66\rangle$

${ }^{85}$ Cowgill et al 1987, 25-7.

${ }^{86}$ Sample no $<65>$

87 1988, 312.

${ }^{88}$ Salzman 1940, 159.

${ }^{89}$ Taylor 1940, 26.

${ }^{90}$ Warne 2009, 4-7

${ }^{91}$ Ibid 2009, 6-8.

${ }^{92}$ Sample no $\langle 42\rangle$

${ }^{93}$ Witney 1976; Everitt 1986.

${ }^{94} 2000$.

${ }^{95} 2009$.

${ }^{96}$ Witney 1976, 78-103.

${ }^{97}$ Mawer and Stenton 1929, 269.

${ }^{98}$ Warne 2009, 12.

${ }^{99}$ Smith 1956b, 257-63; Coates 1999, 32.

1002006.

101 Rippon 2002; Costen 2011, 106.

102 See Rippon 2000.

${ }^{103}$ Everitt 1986, 144-55.

104 English Heritage 2006a, 6

105 1974, 94.

${ }^{106}$ Dyer 1986, 35-6.

107 Tebbutt 1981.

${ }^{108}$ Barford 1990.

${ }^{109}$ Bridbury 1955, xv; Rippon 2000, 42.

${ }^{110}$ Fox 2000, 58.

111 Watts 2003.

${ }^{112}$ Dyer 1995.

${ }^{113} \mathrm{Ibid}$.

${ }^{114}$ English Heritage 2006b, 25.

${ }^{115}$ Dyer 1995, 139.

${ }^{116}$ English Heritage 2006a 62, 67.

117 Lewis et al 1988, 113-15.

${ }^{118}$ English Heritage 2006a, 67. 
119 Pelham 1934, 131.

${ }^{120}$ Gardiner 1999, 38.

${ }^{121}$ Ditchfield and Page 1906, 305.

122 Everitt 1986.

${ }^{123}$ Margetts in prep.

124 Winchester 2003, 114.

${ }^{125}$ Winchester 2003, 33.

${ }^{126}$ Winchester 2010.

1271985.

${ }^{128}$ Baildon 1906, xxx

${ }^{129}$ BL ADD MS 5684.

${ }^{130} 1981,8$.

131 Hudson 1987, 26.

132 TNA SC 12/15/46.

133 Penn 1984, 115.

${ }^{134}$ Salzman 1940, 159.

${ }^{135}$ Warne 2009, 19.

136 Lamond 1890, 108.

${ }^{137}$ Holt 1964, xliv; Hey 1996, 213.

${ }^{138}$ CCA-DCc-ChAnt/M/244A.

139 TNA Eccl 2-22-159-270B; Holt 1964, 57.

$140 \mathrm{Ibid}, 127$.

${ }^{141} \mathrm{Ibid}, 23$.

142 2011; 2013.

${ }^{143}$ Hanson and Wickham 2000; Rippon 2008, 27.

${ }^{144}$ Everitt 1986, 121-3.

145 1986, 35.

${ }^{146}$ Faith and Fleming 2012. 